\title{
Introduction: Buddhist Argumentation
}

\author{
Tom J. F. Tillemans
}

Published online: 1 February 2008

(C) Springer Science+Business Media B.V. 2008

The present volume contains ten papers that were initially read at the conference of the International Association for the Study of Argumentation in Amsterdam in 2006. The conference convenors had rightly seen the interest that the study of nonWestern material should have for a broad-based and informed approach to argumentation in the world and had thus proposed a panel on "Buddhist Argumentation", providing an occasion for Buddhist Studies specialists to draw attention to the interest of the material available and contribute to a future dialogue on common interests. Our introduction here is designed to give something of a working idea of the place of argumentation for Buddhists; we will take up the key concepts figuring in the Buddhists' own writings on argumentation, give some historical and bibliographical orientation, and along the way highlight areas of potential theoretical interest. The papers themselves will provide in depth treatments of particular aspects and questions and, we are convinced, show the sophistication and relevance of this non-Western material.

Let us say from the outset that we will use the term "Buddhist argumentation" to cover both public activities, like debate, and internal reasoning processes, or "arguments in one's head." Taking the term in this wide sense is partly in keeping with prominent Buddhists' own theories, and is brought out by their term anumāna, "inference", under which they understand both the internal reasoning processes one has "for oneself" (svārtha) as well as the verbal presentations of this reasoning that one formulates "for others" (parārtha), i.e., in public argumentation or debate. The details will be developed below. That said, the gravest (and still not uncommon) mistake is to think that there simply is no such thing as Buddhist argumentation and reasoning, or if there is, it is of little significance, because Buddhists (or perhaps genuine Buddhists)—so the oft-repeated story goes—do not value rational thinking and argumentation, being supposedly engaged in another, more non-conceptual,

T. J. F. Tillemans ( ()

Department of Oriental Languages, University of Lausanne, Lausanne 1015, Switzerland

e-mail: Tom.Tillemans@unil.ch 
approach to understanding in which argumentation has no place. The corollaries of this unfortunate denigration are immediate. One needs only to look at the statement of the British philosopher, Anthony Flew, about there not being argumentation in Eastern Philosophy to realize that for many philosophers the supposed absence of argumentation also meant the absence of philosophy tout court. Here is how Flew put it, in somewhat embarrassingly candid fashion, in his Introduction to Western Philosophy, published in 1971:

... philosophy, as the word is understood here, is concerned first, last and all the time with argument. It is, incidentally, because most of what is labelled Eastern Philosophy is not so concerned-rather than any reason of European parochialism - that this book draws no materials from any source east of Suez (Flew 1971, p. 36).

In fairness to Anthony Flew it could be said that much of what was popularly labelled "Eastern Philosophy" in 1971-and indeed is often so labelled today in publications proliferating in New Age bookstores-was hardly philosophy at all and was too woolly to qualify as argumented or analytical thinking. That said, a more accurate representation was probably already available in 1971 and certainly is available now, so that the Flew-style dismissal is fortunately no longer acceptable. The persistent Western depiction of Buddhism, or even Asian thought, as somehow essentially meditative, irenic and beyond the fray of argument is probably due more to contemporary needs to idealize the East than balanced, informed intellectual history. It suffices to look at the Upanișads' arguments about the Self, Nyāya literature on the canons of right thinking and reasoning, the Jain literature on logic and epistemology (pramāna), the intricate metaphysical arguments on the problem of universals, the debates about philosophy of language issues, the Brahmanical proofs for the existence of a Creator (iśvara), and many other such matters to realize that argumentation and philosophical analysis have a huge role all through Indian thought. One can equally cite numerous texts in Chinese to show that there too argumentation and philosophy were alive and well in Buddhist, ${ }^{1}$ Daoist, Mohist and Confucian thinkers. Tibetan literature is full of sophisticated arguments and theories about arguments, ${ }^{2}$ as are Pali texts of Theravāda Buddhist schools.

In short, Buddhist thinkers, like their non-Buddhist rivals, have been deeply concerned with logical and rhetorical issues of good and bad reasoning: What follows from what? Which reasons are probative? When are generalizations warranted? What is persuasive to whom? They have also been concerned with questions about how to argue in public, how to clinch debates, which tactics are bona fide, what relevance scripture and school allegiance might have in a debate, etc. They have engaged in elaborate arguments on philosophy of logic, language, metaphysics and ethics, including East-West issues such as the problem of

\footnotetext{
${ }^{1}$ No doubt Far Eastern Buddhist schools, like the Faxiang ("characters of the elements," *dharmalaksana) school of Xuanzang and Kuiji in the Tang Dynasty, did have a considerable theoretical literature on the canons of argumentation. The distinct contributions and character of this Chinese yinmingxue ("study of reasoning") are, alas, out of the scope of this volume.

2 On Tibetan Tshad ma literature (i.e., epistemology and logic), see e.g., Dreyfus (1997), Tillemans (1999), Hugon (2002), van der Kuijp (1983).
} 
universals, technical matters such as problems of identity, referential opacity and the Liar paradox, and key issues of the philosophy of mind, such as mind-matter dualism, mental causation and reflexive awareness, to take but a few examples.

Of course, the concern with argumentation, reasoning and philosophy varied from one Buddhist school to another and even from one region or historical period to another. It is clear that within India, Tibet and China there were schools of Buddhist thought that questioned the general value of argumentation and reasoning, emphasizing instead ritual, devotion, yogic exercises and/or meditation, and that the place and religious value of reasoning even became itself a debated topic differentiating traditions of Buddhism. Nonetheless, this certainly should not be exaggerated: much of the most important Indo-Tibetan Buddhist literature was chock-full of argumentation, with a scrupulous attention to logic, epistemology and precise use of language. ${ }^{3}$ In this vein too, it is interesting to see that already in early literature on debate, Buddhists found compelled to defend vigourously the ethical value of argumentation-see the discussion in the Fang Bian Xin Lun (translated in this volume in the article by Brendan Gillon), where we see strong Buddhist defense of the practice of debate against the charge from an anonymous opponent that debate is just an exercise in immoral self-promotion, vanity and aggression. The reply that this need not be so and that there are high-minded debates is a recurrent Buddhist position.

Buddhist schools were thus strong in their advocacy of argumentation as a legitimate and necessary activity in which sincere truth-seekers should engage. Moreover, it was promoted as leading to truths independently of reliance upon scripture, school affiliations and dogma. Indeed in the theoretical literature on debate ( $v \bar{a} d a)$ and epistemology (pramāna), argumentation and reasoning take clear priority over faith and sectarian allegiance. The Buddhist recognized that if it were otherwise there would be a clear danger of circularity, for argumentation and reasoning were deemed to constitute the tests as to whether the scriptures and doctrines promoted by a school were true; the Buddhists thus maintained that the school's doctrines and scriptural passages could have no role in their own evaluations (Tillemans 2000, pp. 78-80; on Buddhist scriptural argumentation see Tillemans 1993, 1999, Ch. 1-3).

Granted certain non-Buddhists (e.g., Bhartrihari) maintained that scripture was more reliable and that it trumped reasoning, i.e., "inference" (anumāna). The Buddhist's position, however, was strikingly opposed to this: objective inference that was based on facts (vastubalapravrtta) was the means, and the only means, that rival parties could use to adjudicate factual matters: scriptures were just words and, as such, had no connection with facts. At least in their theoretical literature on

\footnotetext{
3 What about magic and the use of miracles? How much of a place did they have? The tactic of settling philosophical issues by overpowering the opponent supernaturally was-as Cabezón shows in examining the accounts of famous Buddhist debates and debaters (e.g., Dignāga, Aśvaghoṣa, Āryadeva and others)— not prized by Buddhists to anything like the degree it seems to have been by non-Buddhists. See Cabezón, this volume, no. 26: "Magic is at most a means to confirm a victory gotten by verbal or rational means. In the Buddhist texts being examined here, using magic as a means to victory is tantamount to cheating, or else, as in the case of Dignāga, the way in which defeated non-Buddhists exact revenge on their Buddhist opponents."
} 
debate and epistemology, Buddhists consistently advocated an ideal version of reasoning as objective, dispassionate and capable of attaining truth without prior faith commitments or even affiliation with a philosophical or religious school of thought. As Sara McClintock shows in her article in this volume, these Buddhist theoreticians speak at length of a model philosopher, the "judicious person" (prekșāvant): it is this type of ideal person who would reason in such a pure, neutral fashion, by objective inference.

An advocate of the irenic nature of all things genuinely Buddhist might reply that argument and reasoning should be relevant to Buddhists only in their relations with other rival schools (Buddhist or non-Buddhist), ${ }^{4}$ and that a practicing Buddhist- the most extreme case being a meditator in solitary retreat in the mountains-would not have any use for discriminative thought processes and their verbalizations to develop her own understanding of the truth and liberate herself from the clutches of samsāra (the realm of rebirth and suffering). Again the idea would resonate with many popular Western depictions of Buddhism. But although some Tibetan and Chinese thinkers would side with this picture, ${ }^{5}$ it is largely wrong as a depiction of mainstream Indo-Tibetan scholastic Buddhism. ${ }^{6}$ Many major Indian Buddhist schools and their Tibetan successors saw argumentation, conceptual analysis and epistemological reflection as not merely outwardly oriented, but as an important, even integral, part of a Buddhist's own spiritual practice. For them argumentation and analysis was not just used in relations with the "heretics," or non-Buddhist world, or with other rival Buddhist schools, but had an indispensable personal focus as a method for the Buddhist himself to overcome his own ignorance and doubts about doctrinal matters, and especially to deepen his understanding about the ultimate status of all phenomena, i.e., their emptiness, or lack of any inherent properties that make them what they are. The Buddhist also reasoned internally and, in effect, argued with himself. As we see in scholastic texts on Buddhist meditation, such as Kamalaśîla's Bhāvanākrama, the goal may have been an irenic nonconceptual understanding of emptiness, but the path to it was not.

A brief look at the Buddhist theoretical literature on how to argue and reason rightly. The first such literature on argumentation for Buddhists was the debate manuals, i.e., the treatises on $v \bar{a} d a$ of such famous authors as Vasubandhu, Asanga, Dignāga, and Dharmakīti. These manuals, with titles like Vādavidhi (Rules of Debate), Vādavidhāna (Methods of Debate), Vādanyāya (Logic of Debate), were often surprisingly practical and gave explicit rules and procedures for what had to be

\footnotetext{
${ }^{4}$ Note that the defense of debate in the early text, the Fang Bian Xin Lun (translated in this volume by Brendan Gillon), does seem to go in this direction-debate is useful to spread the doctrine and defend it from confused and malicious adversaries. Other, generally later texts, see a kind of internalized argumentation as also having value for oneself, or as even being indispensable for one's own spiritual progress.

${ }^{5}$ The issue comes up as the subject of a very important debate in the early history of Tibetan Buddhism, i.e., the famous 8th century debate pitting the quietist Chinese monk, Hvashang, (and some Tibetan followers) against the camp of the "mainstream" Indian paṇit, Kamalaśîla. See Demiéville (1987) and Seyfort Ruegg (1989).

${ }^{6}$ For a study of Indo-Tibetan scholasticism, see Cabezón (1994). For the question of the scholasticism's view of the connection between epistemology and spiritual matters, see Steinkellner (1982), Tillemans (1993).
} 
said and when. Questions of fairness in argumentation, legitimate tactics, motivation, evaluation and so forth came up frequently. ${ }^{7}$ By the 5 th century C.E., justificatory issues of knowledge-claims came to the fore, giving rise to the literature concerning pramāna, "instruments/means of knowledge", or less literally, "epistemology." The key text that begins this epistemological turn is the Pramānasamuccaya of Dignāga (6th C.); this text then leads to the Pramānavārttika and other works of Dharmakīti (7th C.) with their considerable commentarial literature both in India and in Tibet. It is fair to say that after Dharmakirti the vāda literature diminishes in importance, being superseded by epistemology, as is evidenced by the fact the subject of public debate tends to become one chapter amongst others in larger works on pramāna that deal with various issues of right reasoning and knowledge-claim justification, including issues such as the reliability of perception, testimony and scripture.

Turning to basic notions, the way the $v \bar{a} d a$ and pramāna literature, and many other types of texts, represent the mental process of reasoning is that one thinks: " $A$ is $B$ because of being $C$, like $D$," where one invokes a logical reason, or grounding property (hetu), $C$, to prove the truth of the conclusion $A$ is $B$. The example $D$, which is actually sometimes omitted, is a commonly acknowledged case of $B$-ness and $C$-ness that permits an individual to understand that all $C$ 's are indeed $B$ 's. (The indispensability or dispensability of the example becomes a hotly debated topic amongst later theoreticians.) There is also an important variant on this form where the truth of $A$ is $B$ is not being established, but only the fact that it would follow from an acceptance of $C$. Thus, we can have a type of use of reductio ad absurdum known as prasanga, or tarka: "It would follow absurdly that $A$ would be $B$, because of being $C$." Both these structures are to be found in Indian and Tibetan writing on a variety of subjects.

Since Stcherbatsky's (1958) two volume study and translation of Dharmakīrti's Nyāyabindu, entitled Buddhist Logic, one often sees the Buddhist theory of reasons/ grounding properties designated as "logic", a term that sometimes has the unwanted effect of leading readers to think that good reasons for Buddhists are simply those that are formally valid. In fact, the notion of formal validity (i.e., the conclusion's being guaranteed true, provided the premises are true) is not itself explicitly discussed by Buddhist theoreticians; it is in any case not distinguished from other, more informal, considerations.

Instead of formally valid reasons, Buddhist theoreticians developed the notion of a good reason (saddhetu, Tibetan rtags yang dag), i.e., one which satisfies a triple criterion (trairüpya). These three criteria for "goodness" are given in the following fashion from Dharmakīti on:

(a) paksadharmatva (the logical reason's being a property of the subject): the subject, $\mathrm{A}$, is ascertained as having the property $\mathrm{C}$.

(b) anvayavyapti (positive concomitance): $\mathrm{C}$ is ascertained as present in only instances similar to A insofar as they possess B,

\footnotetext{
7 For the Vādavidhi, see Frauwallner (1982). See also the Nyāyapraveśa, translated and explained in Tachikawa (1971), a text which is quite close in spirit to Dignāga's vāda work, the Nyāyamukha. See also the article by Brendan Gillon in his volume for an example of an even earlier Buddhist vāda text.
} 
(c) vyatirekavyāpti (negative concomitance): $\mathrm{C}$ is ascertained as wholly absent from instances dissimilar to A insofar as they do not possess B.

True, in texts like the Hetucakra of Dignāga, a version of the triple criterion (trairüpya) for good reasons and the operators "partial presence", "complete presence", "complete absence" were correlated to yield a series of nine types of reasons, types that are abstracted from content and subject matter. Not inappropriately, the great historian of logic, Innocentius Bochenski, in the chapter on Indian Logic in his History of Formal Logic, stated that the Hetucakra thus suggested an awareness of formal considerations. Chi (1984), in his Buddhist Formal Logic, went several steps further and attempted to show that the Hetucakra, taken in its formal aspects, might present a number of interesting features to a modern logician. That being said, there is much more to "good reasons" satisfying the triple criterion than simple formal validity: the term "ascertained" (niścita), when unpacked by Dharmakīrti and his commentators, demands that good reasons must be sound (i.e., the premises must in fact be true and the conclusion must follow from them), that the opponent must know they are sound, and that they must be convincing to the opponent who has the appropriate "desire to know" (jijñassā) something he does not already know. This latter demand leads to a host of other requirements: in order to be convinced of something new the opponent must have the requisite doubt, understand the terms and accept the subject of debate. In short, good reasons involve formal considerations (what follows from what? ${ }^{8}$ ); factual considerations (what is so? what is true?); epistemic considerations (what does one need to know in order to know such and such? when is doubt possible?); and what can be termed "rhetorical considerations" (what is newly convincing to whom?). The weighting of these aspects in the theory of the trairüpya also changes over history: at certain points what were factual matters-e.g., the de facto absence of the reason in the similar instances in the case of certain rather special types of arguments-become epistemic matters-e.g., that one cannot know the reason to be present in the similar instances. ${ }^{9}$

Later theoretical elaborations by Dignāga, Dharmakīrti et al. about how to present publicly a good reason (saddhetu) to an adversary in a debate prescribe the

\footnotetext{
${ }^{8}$ Actually, Buddhists seem to have differed significantly on whether satisfaction of the triple criterion guaranteed the truth of the proposition to be proved, i.e., that the proposition must be true if the reason satisfies the requisite triple criterion. Up until and including Dignāga, it seems that Buddhists acknowledged that there could be certain types of good reasons, e.g., the so-called "antinomic reasons" (viruddhāvyabhicārin), that nonetheless lacked this feature of guaranteed truth conservation and proved two opposing conclusions. With Dharmakīrti, however, this scenario of reasons satisfying the triple characteristic for two opposing conclusions is thought to be impossible. See Tillemans (2000, pp. 92-95), concerning "antinomic reasons". See also Oetke (1996) on the question of whether Indian logic is monotonic or non-monotonic (i.e., promoting guaranteed truth conservation or not).

9 The reasoning in question is the notorious asādhāranānaikāntikahetu (reason which is uncertain because of being too exclusive), which occurs when the subject $\mathrm{A}$ is coextensive with the reason $\mathrm{C}$. Taking the epistemic interpretation of the problem, it is said to be impossible to know that all C's are B, because there is no example, $\mathrm{D}$, of a $\mathrm{C}$ and $\mathrm{B}$ which is not $\mathrm{A}$. The factual interpretation is to say that C's are not present in the similar instances because such instances should be similar to A in possessing B, but should not actually themselves be A's. See Kajiyama (1958), Tillemans (1999, Ch. 5).
} 
use of complex structures known as prayoga (formal reasonings). ${ }^{10}$ Thus, for example, the standard formal reasoning that Dharmakirti and his Indo-Tibetan successors prescribed was a two membered quasi-syllogism, known as an "inference-for-others" (parārthānumāna):

All $C$ 's are $B$ 's, like $D$.

$\mathrm{A}$ is $\mathrm{C}$.

Commentators make an explicit correlation with the triple criterion (trairüpya). Thus the first statement perspicuously expresses the positive and negative concomitance (anvayavyāpti, vyatirekavyāpti) and the second expresses the fact of the reason being a property of the subject (paksadharmatā). The conclusion, $A$ is $B$, is, curiously enough, omitted in these later prescriptive accounts of how Buddhists should argue. This is supposedly because the only function of such a form is to show "provers" (sädhana), and a conclusion cannot prove itself: $A$ is $B$, i.e., "what is to be proved" (sädhya), will be understood indirectly.

This prescribed form is typically used when an author seeks to show rigour and legitimacy through conformity with theory. It is, however, only sparingly used in the "working argumentation" found in most philosophical texts and it is not clear at all how often it was used in actual oral debates in India. The little evidence that we do have of such debates in India tends to show that they were not particularly formal and rigorous; in Tibet there is some evidence that certain monasteries (probably seeking conformity with Indian strictures) did advocate a two-membered formal reasoning, but in any case the actual form of debate that became so prevalent and important in Tibet, what is often termed the "logic of sequence and reason" or "thal-phyir logic", is quite different from these inferences-for-others and consists rather in a sophisticated variant upon the "A is B because of C" structure (see Dreyfus, Hugon, Liberman, present volume. See also Tillemans 1999, Ch. 6).

This much will have to do for a basic understanding of the key notions. For a more ample traditional account, the best starting point, in our opinion, still remains Mokșākaragupta's Tarkabhāṣā, a sophisticated but accessible late Indian Buddhist text that Yuichi Kajiyama translated and explained under the title, An Introduction to Buddhist Philosophy (Kajiyama 1966).

The articles in this volume. The reader unfamiliar with the history of argumentation, logic and epistemology in India can profitably begin by consulting the article of Brendan Gillon, "An Early Buddhist Text on Logic: Fang Bian Xin Lun." 11 Gillon gives a sample translation of a Buddhist debate manual that may

\footnotetext{
10 The above form of the inference-for-others is certainly not the only form that Indian thinkers advocated: pre-Dharmakīrti Buddhists did advocate a three-membered form including a statement of the conclusion; non-Buddhist Naiyāyikas advocated a five-membered form; there were even some thinkers who prescribed a formal reasoning with ten members including statements of what is in doubt, the goal of the argument, the possibility of a solution, etc.! What we find is that a considerable amount of sophisticated philosophy of logic and argumentation is done over precisely those issues of what should and should not figure in a formal reasoning, as generally the answers to those types of questions will, for Indian thinkers, be based on a larger conception of what logic is and how reasoning functions. See Tillemans (1999, Ch. 4).

11 The bibliography is also valuable in this regard. A sample of some other reference works:

E. Frauwallner's various articles on Indian logic in his Kleine Schriften; Hattori (1968), Oberhammer
} 
have been written by Nāgārjuna (2nd-3rd Century C.E.), although the Sanskrit title is unknown and the text is only extant in Chinese translation. The interest of the text is that it was probably written well before Asanga and Vasubandhu (4th and 5th Century C.E.), who are the earliest identified authors of Buddhist $v \bar{a} d a$ texts. Gillon precedes his translation with a background section summarizing major developments in the early period. He also discusses in a nuanced fashion in what sense Indian logic is logic. For Gillon, there can, in general, be logics elaborated from an ontic point of view, an epistemic point of view, a dialectic point of view or a linguistic point of view. Indian (and hence also Buddhist) thinking on logic proceeds in the terms of the ontic, epistemic and dialectic, but did not pursue a linguistic account, as one finds often in modern logic. It investigated the conditions under which one set of facts required the existence of another, one type of knowledge required or permitted another and one acceptance required another, but not the conditions under which one statement could be derived from another. ${ }^{12}$

Sara McClintock, in "Rhetoric and the Reception Theory of Rationality in the Work of Two Buddhist Philosophers," examines the Buddhist ideal of the prekșāvant "judicious person", or prekșāpūrvakārin, "person who undertakes an investigation prior [to acting]", who engages in debate in a purely cooperative, nonaggressive, effort to seek truth. This ideal individual is the model thinker promoted at length by the 8th century Indian Buddhist authors, Sāntarakșita and Kamalaśîla, who followed in the footsteps of the Buddhist epistemologist, Dharmakīti. McClintock looks at the "New Rhetoric's" key notion of a rhetorically constructed "universal audience" to which philosophers implicitly address their arguments; she seeks to understand what constitutes the universal audience for the two Buddhist thinkers in question and finds that it is essentially one composed of judicious people, i.e., ideal people who embody the standards of rationality. She concludes by considering the ways in which Śantarakșita and Kamalaśîla may be seen as embracing a rhetorical conception of reason.

Georges Dreyfus, in "What is Debate for? The Rationality of Tibetan Debates and the Role of Humor," examines Tibetan monastic debate as practiced in the Geluk (dge lugs) scholastic education up to the present day. The ideal of debate in Tibet seems essentially similar to that advocated in the Indian theoretical literature (cf. the article by McClintock): argumentation and reasoning are used to gain

Footnote 11 continued

(1991), Kajiyama (1989), Matilal (1971, 1998) as well as the introduction to Matilal and Evans (1986), Mimaki (1976), Dreyfus (1997). There are also articles (and short bibliographies) on Indian logic, philosophy of language and epistemology in the Routledge Encyclopedia of Philosophy, ed. E. Craig, London, 1998. See also the issue on Buddhist logic in G. Paul (editor), Hōrin. Vergleichende Studien zur Japanischen Kultur 11, Düsseldorf, 2005.

12 This is certainly right: a typical investigation for Buddhist thinkers is to enquire how it is that one fact "establishes" another, or to use the Sanskrit terms, how such and such a thing is a sign (linga, evidence) for another. Cf. Dharmakirti's rejection of the linguistic perspective in favour of the ontic in Pramānavārttika IV, k. 15 (Tillemans 2000, pp. 26-27): "One understands one state of affairs from another. Thus the statements of the thesis and reason have no power with regard to the state of affairs [in question, i.e., that which is being proved]. Hence, these two [statements] do not, in themselves, constitute means of proof (sādhana)." (arthād arthagateh śaktih pakṣahetvabhidhānayoḥ/nārthe tena tayor nāsti svatah sädhanasamsthitih //) 
well-founded conviction in the truth of the Buddhist positions and scriptures. And pedagogically this ideal translates into an "edificatory progression toward the formation of the person on the basis of a rational inquiry leading to an increasing certainty" (Dreyfus, this volume). Nonetheless, in practice Geluk debate invariably involves intrusive rhetorical elements, such as humor, that prima facie might not seem to fit with the ideals. Dreyfus begins by detailing the rules and procedures of Geluk debates. The intrusive elements that he investigates escape the codification and rules of debate, but are nevertheless integral to its practice and even partake deeply of its goals. In parallel to the ideal edificatory progression where debate is to generate well-founded certainty, the practice of debate, and its resultant destabilization, leads to the development of a sense of the fragility and tentativeness of all interpretations (see also Dreyfus 2003).

Kenneth Liberman, in "Sophistry In and As its Course," also examines features of actual Geluk monastic debates. He sees these debates as providing evidence for the wider thesis that sophistry and good philosophical reasoning, though they may be distinguished theoretically and normatively, are never separate in actual philosophical practice. Whether sophistry helps or hinders reason is not primarily due to recurring features stemming from the natue of sophistry (if any), but rather to what debaters actually do with it. Thus, focusing on Tibetan debate, where sophistry is used in a skillful and controlled manner, Liberman uses ethnomethodological methods to investigate when and how sophistry is profitably used to enhance and develop philosophical understanding by closing down "dead-ends" and opening new perspectives. Liberman transcribes and analyzes actual Tibetan debates, looking at how order is created, how clarification proceeds, how demands for consistency operate and how at key stages the tables are brusquely turned in a constructive fashion (see also Liberman 2004).

In "Buddhist Narratives of the Great Debates," José Cabezón examines Chinese and Tibetan narrative accounts of great Indian Buddhist debates, looking especially at historical and hagiographical literature. Cabezón does not treat these narratives of debate as themselves rigorous history, nor as legend, but as a literary form, part of a theme of contests (verbal and magical) by which the great Indian Buddhists vanquished their opponents. Whereas philosophical literature often gives a detailed account of the content, the narrative literature creates tales of heroes, suspense, divine intervention, intrigue, and punishing defeats; with these stories of exploits, Buddhists develop their sense of identity as people having a shared relationship with the Indian past. As Cabezón suggests, the narratives of debates are also themselves forms of argument, arguments that invoke (real or legendary) events in the life of philosophers to make the case for the philosophical positions that these scholars held.

Pascale Hugon, in "Arguments by Parallels in the Epistemological Works of Phya pa Chos kyi seng ge," takes up a style of Buddhist argumentation that became frequent in certain Tibetan circles, i.e., elaborate arguments by parallels and analogies. Because the works of Cha-ba Chö-kyi Seng-gay (Phya pa chos kyi seng ge 1109-1169) were until recently unavailable, a number of fanciful claims had been regularly made about him being the founder of the peculiarly Tibetan thalphyir ("logic of sequence and reason") type of argumentation used in Geluk debates from about the 16th century onwards. In fact, as Hugon shows, his style of 
argumentation was quite different and much less rule-bound. Cha-ba is not, therefore, likely to be the founder of the "logic of sequence and reason" so characteristic of modern Tibetan monastic debates. What we see is that argumentation in Tibet also often proceded in a tit-for-tat fashion, with one party offering a parallel, the other party disputing the parallel or offering a counter-parallel and so forth.

Assertion: $\mathrm{P}$

Reply: "No, because if $\mathrm{P}$ were so, then $\mathrm{P}^{\prime}$ would be so, since it is analogous to $\mathrm{P}$ " Rejoinder: "No, $\mathrm{P}^{\prime}$ is not analogous, because...".

This type of argumentation by parallels is not given any substantial theoretical role in Indian vāda and pramāna literature, although it (or some variant upon it) may also have been quite prevalent in India. It does, however, present an intricate structure that Hugon brings out in her article.

In "Classes of Agent and the Moral Logic of the Pali Canon," Martin Adam seeks to investigate Buddhist ethical reasoning as found in the early Buddhist writings of the Pali Canon. He looks at two Pali terms, "meritorious/merit" (puñna) and "wholesome/wholesomeness" (kusala) that occur as the basic vocabulary used in contexts describing good actions. These terms are to be understood in relation to three different types of agents, i.e., (a) ordinary beings (puthujjana), who are unfamiliar with selflessness, (b) disciples in higher training (sekha), who have had a first experience of selflessness but have not yet attained nirvāṇa, and (c) liberated beings (arahant), who have attained nirvāna, eliminating all rebirth by extirpating the wrong view that there is a self as well as all desires conditioned by such a wrong view. Martin Adam argues that as people's conduct and their reasoning about such conduct is distinguishable on the basis of their proximity to nirvāṇa (nibbāna), notions of goodness will also vary in function of types of agents: meritorious actions are those that lead to better rebirthsthe typical concern of an ordinary being; wholesome actions are conducive to nirvāna - the concern of a disciple in higher training.

The three articles that close this volume are philosophical analyses of particular issues that have significant connections with Western discussions. Mark Siderits, in "Contradiction in Buddhist Argumentation," challenges the idea that (some or all) Buddhists interestingly flaunt or explicitly reject the law of non-contradiction. The idea that they deliberately do, or at least that some of the more radical amongst them do, has a long history with illustrious advocates, including Edward Conze, Hajime Nakamura, Jacques May, and others. Recently the philosopher, Jay Garfield and the logician, Graham Priest, in their joint article, "Nāgārjuna and the Limits of Thought", have given this idea new life by arguing that certain Buddhists have seen that there are genuine paradoxes when dealing with totalities of entities. ${ }^{13}$ To make sense of this, Garfield and Priest rely on paraconsistent logic, i.e., formalizations of logic that do not allow everything to follow from a contradiction. Nāgārjuna was (at least implicitly or in a reconstruction of his philosophy) an advocate of "dialetheism", i.e., the position that some contradictions are true-for some statement $\varphi, \varphi \& \operatorname{not}-\varphi$ is true.

13 The joint article appears both in Priest (2002) and in Garfield (2002). 
Garfield and Priest seek to argue that some statements of contradictions in Nāgārjuna's Madhyamaka ("Middle Way") philosophy can best be taken as true, notably those along the lines of "the intrinsic nature of things is that they have no intrinsic nature", implying that things both do and do not have intrinsic natures. Siderits argues that such types of Nāgārjunian statements are not asserting that things, as they ultimately/intrinsically are, are contradictory, but that these statements bring out a general presupposition failure in realist discussions: there is no ultimate way things are at all that will serve as the subject matter for various predicates. Relying on Paul Grice's idea of conversational implicatures, Siderits argues that a contradictory formulation may have the conversational implicature that the presupposed subject matter (i.e., how things are intrinsically) is lackingthis, according to Siderits, would the best reading of Nāgārjuna, rather than a reading where Nāgārjuna would accept that there is a contradictory way in which things intrinsically are.

Dan Arnold, in "Transcendental Arguments and Practical Reason in Indian Philosophy", looks at the non-Buddhist Mīmāṃsaka and Buddhist Madhyamaka uses of a type of argumentation that is similar to Kantian transcendental argumentsarguments whose conclusion cannot be challenged without self-contradiction; the truth of the conclusion would be a condition for such a challenge to be even possible. In short, transcendental arguments seek to establish that a necessary condition of a challenge to a claim's intelligibility is that the claim must be true. Let us focus on the Madhyamaka Buddhist's argument: the Mīmāmsaka argument has similar structural features, even if its doctrinal standpoint is quite different. ${ }^{14}$

The Madhyamaka, when confronted with a realist's challenge to his claim that things lack any intrinsic nature, has an elaborate reply designed to show that if things actually had intrinsic natures, no true, or even intelligible, statement or judgment would ever occur, including the realist's challenge. The point is that statements and judgments-like everything else in the universe-are what they are completely because of conditioning by other things; having an intrinsic nature would preclude them from being products of the conditions that make them what they are, so that if they had intrinsic natures they simply could not arise and function.

The realist's challenge is thus not possible without the truth of the Madhyamaka claim. But in what sense is it not possible? Is the truth of the Madhyamaka (or Mīmāmsaka) claim logically necessary and its challenge logically impossible; is the Madhyamaka claim, then, what a Kantian could term a truth of theoretical reason? Arnold argues that this is not the sense of necessity and possibility at stake: rather, the truth of the Madhyamaka (and Mīmāmsaka) claims is because challenge is a performative, or practical, self-contradiction. To take an analogy: a modern-day Western materialist challenge to the existence of minds or to thinking subjects incurs the problem that, if it is right, one cannot imagine how I could actually think of such a challenge. Eliminative materialists, of course, deal with such problems by

\footnotetext{
14 Faced with a challenge by certain Buddhists, who hold that all relations between words and objects are man-made, the Mīmāmsaka argues that language learning presupposes that not every word-object relation is arbitrary, and that there must always be some language where the word-object relation is fixed-failing that the Buddhist challenge itself would end up meaningless.
} 
seeing them as erroneous hold-overs from outdated folk theories, so that the supposed requirements of practical reason are superseded by the advances of theoretical reason. As Arnold argues, the Madhyamaka has a different stance and privileges the worlds' practical requirements, which are immune to theoretical attack: practical trumps theoretical reason for Madhyamaka.

Finally, Tom Tillemans, in "Reason, Irrationality and Akrasia (weakness of the will) in Buddhism: Reflections upon Sāntideva's Arguments with Himself”, looks at the place Buddhists accord to a type of irrationality in their behavior and thinking. In particular, he focuses upon a recurring theme in the writings of the 8th century Buddhist thinker, Santideva, who subjects his own behavior and thought to minute scrutiny in argumentation with himself, only to be confronted with the fact that he seems to persist irrationally in ways of thinking that he knows to be wrong and that he pursues actions he knows to be worse courses. The problem and puzzlement surrounding pursuit of error and worse courses are profitably comparable to issues of akrasia, weakness of the will, that are taken up by Plato, Aristotle and many modern philosophers, including notably Donald Davidson and David Wiggins. While taking Sāntideva seriously suggests that at least some important Buddhists were "bitten" by problems of akrasia, there is in certain modern representations of Buddhism as an "art of happiness" a tendency to dismiss seemingly knowing choices of worse courses as just in fact cases of ignorance-one does not really believe in or know the best course (i.e., the one maximizing happiness/utility), for if one did one would invariably pursue it. This too is reminiscent of the Socratic defense of human beings' rationality, one that dismisses akrasia as a pseudophenomenon. Tillemans in the latter half of the article seeks to show that there are, on a charitable reading of Mahāyānist Buddhist philosophical literature, the makings of a complex theoretical account of akrasia that does not explain away the all too human phenomena of genuine conflict and knowing choice of worse courses.

Concluding reflections. We began by dismissing the all too widespread ideas that argumentation is (or should be) absent from Buddhism, or that it should be absent from Buddhist practice, etc. Looking at the papers in this volume, it seems that there are two distinguishable sets of questions to pursue if we are to do justice to the place of argument and reasoning in Buddhism: (a) What are the Buddhists' theoretical accounts, in their literature on debate and epistemology, about how people should argue for positions, refute opponents, reason rightly and justify truth-claims? ${ }^{15}$ (b) What are the Buddhists' actual approaches and attitudes to argumentation and reasoning? This involves examining their philosophical, religious and ethical discussions, the role of debate in actual practice in educational institutions, the literary representation of debates and debaters, the historical accounts of debates, etc.

The initial articles dealt largely with the first set of concerns. Subsequently, it was the second set of concerns that predominated in this volume. There is, of course, overlap and even some tension between the two, but significantly there are a number of questions about Buddhists' ways of reasoning that are only partially answerable by plumbing Buddhist theoretical treatises on debate and epistemology.

\footnotetext{
15 For a bibliography of translations, editions and studies of the Indian Buddhist literature on debate and epistemology, see Steinkellner and Much (1995).
} 
As we can see by the articles in this volume, investigations of actual Buddhist argumentation will typically involve logical analysis (e.g., Does the Buddhist respect such and such a theorem? What sort of necessity does he recognize, if any?); questions of reasonableness (e.g., What are the Buddhists' actual standards? Does he recognize any interesting role for thought and behavior that seems in conflict with reason?); rhetorical aspects (e.g., What is convincing to whom?); the use of argumentation in Buddhist centers of learning (e.g., What pedagogical role does debate have? What role is played by sophistry, humor, polemics?); the literary representation of argumentation (e.g., How are the debates and debaters depicted in narrative accounts and hagiographies?). It is highly unlikely that purely philological and historical research centered on $v \bar{a} d a$ and pramāna literature can provide adequate answers to such questions. Several contributions in this volume engage in extensive philosophical and logical analysis using Western notions, some in sociological and ethnomethodological analyses and some analyze rhetorical and literary aspects. All are attempts to treat Buddhist argumentation by making rapprochements with wider theoretical concerns and methodologies. All take what Buddhists say seriously in the way it deserves to be taken.

\section{References}

Cabezón, José I. 1994. Buddhism and language: A study of Indo-Tibetan scholasticism. SUNY Series toward a comparative philosophy of religion. Albany, NY: State University of New York Press.

Chi, R.S.Y. 1984. Buddhist formal logic. A study of Dignāga's Hetucakra and K'uei-chi's great commentary on the Nyāyapraveśa. Royal Asiatic Society of Great Britain, B.C. Law Trust Fund, Vol. 1. Motilal Barnarsidass, Delhi.

Demiéville, Paul. 1987. Le Concile de Lhasa: une controverse sur le quiétisme de l'Inde et de la Chine au VIIIe siècle de l'ère chrétienne. Paris: Collège de France-Institut des hautes études chinoises.

Dreyfus, Georges B. 1997. Recognizing reality. Dharmakīti's philosophy and its Tibetan interpretations. SUNY Series in Buddhist Studies. Albany, NY: State University of New York Press.

Dreyfus, Georges B. 2003. The sound of two hands clapping: The education of a Tibetan Buddhist monk. Berkeley: University of California Press.

Flew, Anthony. 1971. An introduction to western philosophy. London: Thames and Hudson.

Frauwallner, E. 1982. Kleine Schriften, Herausgegeben von Gerhard Oberhammer und Ernst Steinkellner. Wiesbaden: Franz Steiner.

Garfield, Jay L. 2002. Empty words, Buddhist philosophy and cross-cultural interpretation. Oxford: Oxford University Press.

Hattori, M. 1968. Dignāga on perception, being the Pratyakșapariccheda of Dignāga's Pramānasamuccaya. Harvard Oriental Series 47. Cambridge, MA: Harvard University Press.

Hugon, Pascale. 2002. Le rTags kyi rnam gzhag rigs lam gsal ba'i sgron me de Glo bo mkhan chen bSod nams lhun grub. Un manuel tibétain d'introduction à la logique. Wiener Studien zur Tibetologie und Buddhistische Studien 55. Vienna: Arbeitskreis für Tibetische und Buddhistische Studien Universität Wien.

Kajiyama, Yüichi. 1958. On the theory of intrinsic determination of universal concomitance in Buddhist logic. Journal of Indian and Buddhist Studies 7(1): 360-364. Reprinted in Kajiyama (1989).

Kajiyama, Yūichi. 1966. An introduction to Buddhist philosophy, an annotated translation of the Tarkabhāsā of Mokșākaragupta. Memoirs of the Faculty of Letters of Kyoto University 10, Kyoto. Reprinted in Kajiyama (1989).

Kajiyama, Yūichi. 1989. Studies in Buddhist philosophy. ed. K. Mimaki et al. Kyoto: Rinsen.

Liberman, Kenneth. 2004. Dialectical practice in Tibetan philosophical culture: An ethnomethodological inquiry into formal reasoning. Introduction by Harold Garfinkel. Lanham, MD: Rowan and Littlefied. 
Matilal, Bimal K. 1971. Epistemology, logic, and grammar in Indian philosophical analysis. The Hague: Mouton.

Matilal, Bimal K. 1998. The character of logic in India. ed. Jonardon Ganieri and Heeraman Tiwari. Albany, NY: State University of New York Press.

Matilal, Bimal K., and R.D. Evans, eds. 1986. Buddhist logic and epistemology. Studies in the Buddhist analysis of inference and language. Studies of Classical India 7. Dordrecht: Reidel.

Mimaki, K. 1976. La Réfutation bouddhique de la permanence des choses (sthirasiddhidūsana) et la preuve de la momentanéité des choses (kșanabhangasiddhi). Paris: Publications de l'Institut de Civilisation Indienne 41.

Oberhammer, G. 1991. Terminologie der frühen philosophischen Scholastik in Indien. Ein Begriffswörterbuch zur altindischen Dialektik, Erkenntnislehre und Methodologie. With the collaboration of E. Prets and J. Prandstetter. Vienna: Verlag der Österreichischen Akademie der Wissenschaften.

Oetke, Claus. 1996. Ancient Indian logic as a theory of non-monotonic reasoning. Journal of Indian Philosophy 24.

Priest, Graham G. 2002. Beyond the limits of thought. Oxford: Oxford University Press.

Seyfort Ruegg, David. 1989. Buddha-nature, mind and the problem of gradualism in a comparative perspective: On the transmission and reception of Buddhism in India and Tibet. Jordan Lectures in Comparative Religion 13. London: School of Oriental and African Studies, University of London.

Stcherbatsky, T. 1930/32. Buddhist Logic. Two volumes. Bibliotheca buddhica 26, Leningrad. Reprinted by Mouton and Co., The Hague, 1958.

Steinkellner, E. 1982. The spiritual place of the epistemological tradition in Buddhism. Nanto Bukkyō 49 (Nara, Japan).

Steinkellner, E., and T. Much. 1995. Texte der erkenntnistheoretischen Schule des Buddhismus. Systematische Übersicht über die buddhistische Sanskrit-Literatur 2. Abhandlungen der Akademie der Wissenschaften in Göttingen. Göttingen: Vandenhoeck and Ruprecht.

Tachikawa, M. 1971. A sixth-century manual of Indian logic (A Translation of the Nyāyapraveśa). Journal of Indian Philosophy 1.

Tillemans, Tom J.F. 1993. Persons of authority. The sTon pa tshad ma'i skyes bur sgrub pa'i gtam of A lag sha Ngag dbang bstan dar, a Tibetan Work on the Central Religious Questions in Buddhist Epistemology. Tibetan and Indo-Tibetan Studies 5. Franz Steiner, Stuttgart.

Tillemans, Tom J.F. 1999. Scripture, logic, language. Essays on Dharmakìrti and his Tibetan successors. Studies in Indian and Tibetan Buddhism. Boston: Wisdom Publications.

Tillemans, Tom J.F. 2000. Dharmakīti's Pramānavārttika. An annotated translation of the fourth chapter (parārthānumāna). Vol. 1 (k. 1-148). Österreichische Akademie der Wissenschaften, Philosophisch-Historische Klasse, Sitzungsberichte, 675. Band. Vienna: Verlag der Österreichischen Akademie der Wissenschaften.

van der Kuijp, Leonard W.J. 1983. Contributions to the development of Tibetan Buddhist epistemology: From the eleventh to the thirteenth century. Alt- und Neu-Indische Studien 26. Franz Steiner, Wiesbaden. 